http://www.jfas.info

\title{
STUDY OFFICIAL NON- CONCENTRATION SYSTEM BENEFITS BY EMPHASIZE TO SAPAN
}

\author{
E. Molaee* and K. Emadzadeh
}

Department of Public Law, College of Human Science, Bandar Abbas Branch, Islamic Azad University, Bandar Abbas, Iran

Published online: 15 May 2016

\begin{abstract}
Administrative system of each country is essential with direct contact with the people of the importance and credibility. The huge volume of government services through various government departments, so having a coherent administrative system, efficient, transparent and accountable government and policy makers always a problem for any society is considered. In administrative law, govern the country with two systems will be common in all parts of the world, the second focus of the center. Administrative focus of the running and administration of a society in which there is usually the center of gravity. And approaches to administrative reforms with the help of laws and regulations and the actions of other countries in order to create efficient and effective administrative system to be studied.
\end{abstract}

Keywords: Bureaucracy; centralization; decentralization; integrity; Japan.

Author Correspondence, e-mail: entesharat.ban@gmail.com

doi: http://dx.doi.org/10.4314/jfas.v8i3s.190

\section{INTRODUCTION}

Official system in every country is very important due to direct relation to different layer of society. And due to that high volume of government servicers obtain by government different 
canals, so all political men should found one unified, efficiency, clear and respond system. And governments try to add to official system and decrease public un-stratification study necessity regulation and official modification. In the official law, country run is by 2 common systems in all world regions. The first is concentration and second is not concentration. Official concentration is kind of society run. And there is concentration center and every official activity need to let order we have not freedom in this system and the affair are under control one system. And they run by one command center in government legal personality unification is clear and there is no place for doubt. This system is best tool for management in one country or work space and insurance atonal order. In this system run costs divided between all countries people and inhibited loss cost and lead to cost in our country cost and it is for benefit all people. (It is economic) but it has some problems for this official system. Such as absolutely following these commands. (They are under supervision of parts and cities) and these cases lead to non-concentration and lavation of forces and get power and their think. But non- concentration is our major subject for proposal and society run lead to give independence and decision- making qualification of one region, and society. And purpose of this system is people partnership in local affair run to planning for problems and show their solve. In this system we can see give authority to government or local center. One of reasons for this giving is deleted these ceremonies and removed high bad and deleted concentration in this center. It is worth nothing that official healthy in organizations lead to correct decisionmaking and proper apply of policies. And have efficiency state and effective public services. Several factors like efficiency control and supervision, organizational culture, and government structure play role in official healthy realization. If we don't central official non- concentration structure, it can provide important opportunities for realized official healthy. But still we have problem about these issues by support local non- concentration units. This problem root is in social, political, historical and economic issues and it is common in aspect of vagueness and its qualification.

\section{OFFICIAL LAW SPECIFICATIONS}

But one important question is that how we can have one political, social free country by 
minority government and in this case we have one majority-oriented government and they respect to political, social, religious government. They let to political, society and religious parties let to government run and they participated in public \& political life and they make government if it wins in the section. These discussions extend in one- systems and point to them in all power in concentration government ((all political and official)) is in one unified person or group, since in all non- concentration government the power is in all different organizations and the power and abilities divided between different authorities. We can say different sign of to trailer, kingdom system and they point to their definition: official systems threat factors.

1. Political post not- distinction of administer post that have not qualification and hierarchized posts.

2. Employment system duck base on qualification.

3. Not response to performance evaluation system of official systems.

4. Not being organized and defined relation between countries official units.

5. Not being life quantified of some organizations.

6. Permanent employment.

\section{OFFICIAL CONCENTRATION CONCEPT}

Society control is on government duties but control concentration governments are very strict and similar to police governments. Official police governments run the country not society law although in some societies that have not concentration via natural, social, cultural and language geographical this office concentration is necessity. But civil society organizations are under government control and they say about control strict of Germany official system. So they support their public powers one official law and they sense dependence. And they select their member base on qualification. And they say about strict control of German official system of France pattern: ((So they support their public power)). And they have independence and select their member's base on qualification and majority of them were rich man that attach to political system and increase to their power in this century to assign political system representative to themselves. 


\subsection{Official concentration system specifications}

We cannot 2 specifications for official concentration system:

1) Political power concentration in central government.

2) Official power concentration in central government.

\section{NON- CONCENTRATION SYSTEM REVOLUTION TREND IN JAPAN}

It is very soon that we speak about effect of these revolution and polity output. And it is reality that if policy makers be more in ministers and cabinet members select base on their qualifications and be in their post more long they can change power balance toward them. So high grade assistants make session. Support organization unit of ministry and legal authorities to Prime Minister Lead to government can apply in government. So (Kooeezi) is very powerful relative to their past prime minister and have better media personality and it is not simple we say its trend is affect by organizational modification. Still his coalition government is unified after 2003 November selection. If modification leads to support organizational power of prime minister and selective policy maker as public, they soon clear it. Individual don't tend that central government involved in their affairs and apply their opinions to them.

People do not want the central government (CG) in all matters relating to interfere and impose their opinion to people. 2. Politically: a country where racial or religious differences or different parts of the customs there and in terms of geography and economic conditions are different. Administrative decentralization is the best style office because in this way each region according to local needs and requirements of the and a variety of similar and that the results lack of focus disappears. 3. The administrative and technical: State and local interests should be managed by local authorities and agents to center by officers from the experience and knowledge of local authorities freely elected by the people. More than officers in local affairs that are imposed from accounting and administrative system as well as the best means for quick resolution of administrative affairs; because the system does not need a lot to see and communicate with the office from common waste of time and paperwork can be prevented. Experience has shown that in this system, administrative system or uncooperative people more than the administrative authorities and their devices from it and do not hesitate to 
help them. This system makes the tasks of the center lighter and better things run and involve people in the management of local affairs causes the sense of initiative and efforts of individuals rise and increasing government involvement losses that would reduce the loss of private initiative local administration populations by causing local people to participate in the campaign insight and experience necessary to participate in public life now earn. Besides the mentioned advantages, disadvantages can be placed for administrative decentralization, including: 1. politically: Decentralization can be disruptive to countries that do not have a strong stability in these countries, decentralization strengthen the separatist claims and the result will be instability of the political system. 2. Economically: decentralization can cause economic inequality in countries where natural resources are not the same across the country. The fertile areas of economic opportunity and greater prosperity will be more and more areas will be suspended. 3. In other words, in some cases, personal expression can overcome the public interest and that the country's public program will be interrupted. For example, the City Council is decentralization in Iran. In the face of poor economic conditions after the war, what could sponsor more than anything else keeping continues to make promising trend in the economy and life of the people, Check the mechanisms of governance that could take the initiative in the hands of successful economic planning. Naturally, the pre-war administrative structure was put in the service of militarism and conquest, and perhaps more important for the country's transformation strategy goals of the international situation changes, they were not able to meet the needs obviously, the first steps could be taken included the establishment of effective economic institutions and organizations eliminate unnecessary administrative apparatus, At that time, however, the short-term that mainly austerity and limiting the ways they were taken, At the same time, and should be more serious and long-term structural solutions implemented were given the contemplation and consultation. Architected solutions as well if they could have realized that the organizational framework be established in accordance with incompetence that could be the source of policies and decisions architected solutions as well if they could have realized that the organizational framework be established in accordance with incompetence that could be the source of policies and decisions in August 1964 the country into famine, inflation was complete economic collapse altogether, staff 
economic stability was an essential first step that actually constitute the basis of economic planning. General economic policies focused on the planning staff with the high powers that were delegated, exerted full control over how the other ministries controlled tubs in this way, the headquarters of the powerful institution after the war. Although lasted until the disposal of the organization that need to be available and once the desired structure of statehood and procedures were adopted in organized self-serving, Staff was reduced to the same proportion of its mandate and form a Planning Agency paid to do specific tasks. Staff could not have economic stability of the powerful elite organization unless its members individually among the chosen people with different professional backgrounds are educated. The staff managing the economy after the war became general task and this task by planning policies, principles and basic coordination between the devices, Budget development and control the distribution of goods and raw materials was uttered between people and plants. The staff worked under the supervision of a Secretary-General who was not a member of the Cabinet, but not necessarily the most experienced and the most suitable person for the post was. And the other ministers have the authority to bring under its influence. Although the minister was Secretary-General of the Commission. The Committee consists of 316 members in different fields five section or department performed the following tasks: Part I: general planning _ this section to coordinate different programs, which were carried out in various ministries. And therefore it was prevented in various ministries or planning was inconsistent with the objectives and general principles act to neutralize targets. In addition, investment planning and transport policies were the responsibility of this section. It seems that Japan is moving toward a two-party system. The next test is the parliamentary elections in July 2004. Smaller cabinets, ministers are selected mainly on the basis of merit and stay longer in their posts, using more than politicians elected in the Ministries, Ministers to meet certain compulsion to parliament, all subject to the handling of the decision-making process always has said. Is this shift in policy will have better returns? In the same way about the changes that have occurred in the structure of premiership soon cannot judge whether the Prime Minister authorized the exercise of power occurred. Soon we can judge whether the authority of the executive branch increased centralization of power in the Prime Minister or not? It seems "Kueyzomy" is derived from 
the work, but it remains to be evaluated to determine if the work of his successor. This situation is the result of structural changes in the prime minister or the achievement of personal character and popularity of the current prime minister? Finally we can say that the process has been a shift in Japanese politics. The national agenda - that stand against imperialism in the late nineteenth century and the years after 1950 to rebuild the economy this- In order to justify the monopoly of power by central bureaucrats in political rule goes live. Some say these things today that are not bought, "Just in the course of globalization, local identities have become very important," an obvious contradiction. In addition, the central government seems ready to apply the rule of not only local government, but also reduce non-governmental organizations.

\section{CONCLUSION}

In the official law, the run of countries is by 2 different systems. The first is concentration, the second is non- concentration. Since designing one system is by human begin it is natural that these 2 kinds of system have advantages and diced vantages. And we can analysis them. Official concentration: it is kind of running government and it is one center and doing every official activity need to license of center. And there is no automatic freedom in the official organizations. As an example center is boss and other parts and cities are like subordinate. Subordinate cannot do noting with no let of the boss. We can see a clear example of it in our country that Tehran is the official, political, cultural and social, out and exercise center. In their official system, official concentration is under someone command and country run by center by ministers that are high officers for decision making and they usually located in capital. In this kind of official system for example Tehran Islamic culture office, regulated some regulation in capital. And they send to all branches in the cities. Until they act to them base on certain principles. In this unification legal system it is clear that and it is not sign of debt. Sub ordinate relation defined by boss relation. And subordinate has official error and even. We can refer it to official high tribunal. One of other scores of this official system is official hierarchized rule- maker to order it. In this system we can see some authorities in hierarchy like authority for order, education. And subordinate can modified or change it if his 
action was mistake it is interesting that although suborning boss is high grade and is commander but we cannot made decision and don't do something and the most important point is that it violated order in official hierarchy and has some problem. We can note some advantages and disadvantages decide official concentration system. Such as this system is best tool for management in one country or work space and insured public order and national unification. And in this system their cost divided between all peoples and inhibit loss it. And lead to cost effective.

\section{REFERENCES}

[1] Akhoondi, Mohammad civil procedure, first Volume University Jihad publication, winter 1985.

[2] Admit, Fereydoon, concentrational Nehzat ideology, Tehran, Payam, 1973.

[3] Abrahamian, Yerevand, Iran between 2 revolution of Mashrooteh to Islamic revolution, Translated, kazem Firoozmand, Hasan Shams Avari, Mohsen Modir Shanehchi, Tehran, center publication.

[4] Ansar, Valiollah, Official law, Tehran, Mizan publications $5^{\text {th }}$ edition, 1998.

[5] Aabolmohammad, Abdolhamid, Iran official law, Toos publication summer 1980.

[6] Emami Gheshlagh, Mohsen, paper about view to non-official system.

[7] Amani, Mohammad, Sansari Ostovas, Korosh, Tehran, Mizan publication.

[8] Badi, Bartearan, government sociology, translated, Dr. Ahmad Nahibzadeh, Tehran, Gomes 2008.

[9] Bashariyeh, Hossein, political know ledge education, Tehran, 14 editions, 1998.

[10]Tilar, Parvaneh, comparative principle of law, khorsandi publication, first edition, 2008.

[11]Tslimi, Mohammad Saeed, Mashali, Behzad, official federal system pattern.

[12] Hafeziyan, Fatemeh, worker associations in Iran, Tehran, Andisheh bartar publications.

[13]Heydar, Masood, comparative study, Tehran University 1965.

[14]Hokmi, Nasrin, development in Japan, New period social letter, 2 volume, number 1, summer.

[15]Alavioan, Seyyed Mohammad Reza, woman work in Iran law and work international law, 
Tehran, Roshangaran, publication, 1994.

[16]AliAbadi, Abdolhossein, legal principle first volume.

[17] Kamali, Yahya study concentration in official healthy 7 papers, period, 5 numbers.

[18] Katoozian Naser, legal justice, Mizan publication 2 volume. Winter 1992.

[19] Katoozian, legal justice, Mizan publication, Amirkabir.

[20] Katoozian, Mohammad Ali, Iran political economy, Tehran, Amir Kabir, 1986.

[21]Goudarzi, Gholamreza, unfinished modernist intellectuals failed, Ahvaz, authoritative, 2005

[22] Goodarzi, Gholamreza, view to modification, Omid Azadai magazine, 6 numbers.

[23]Langroodi, criminal law terminology, Ganje Danesh publication.

[24]Mohseni, Abbas, familiarity with legal responsibilities, country organization publication.

[25] Madani, Seyyed Jalaleddin, civil procedure, second edition.

[26] Medical and medical education regulation set, 2008.

[27] Votes set of official justice high tribunal, Ferdousi publication.

[28] Moosa zadeh, Reza official law, (1-2), Tehran, Mizan publication, 1974.

[29]Modares, Morteza, Seyyed Jamaloddin Asad Abadi, Tehran.

[30]Moti, nahid, comparasion elit role in Iran \& Japan process, publication Tehran 2008.

[31] Merton, Scoth, Japan culture \& art, Translate, Masood Rajabnia, Tehran 1984- 1989.

[32] Naghib Zadeh, Ahmad, policy \& government in Europe Tehran, Samt, 1995.

[33] eR Esenapa J ,(1991).L treboR ,kralC .niwrI:sionilll,doowemoH,smetsyS ynemerit

[34]See J.A.A.Stockwine; Dicitionary of the Modern Politics of Japan, Routledge Curzon, 2003, p.53.

[35] eR esenapaJ ,(1991).L treboR ,kralC .niwrI:sionilll,doowemoH,smetsyS ynemerit

[36] orihoaN ,awagO dna.L treboR ,kralC sgninraE dna eruneT gniredisnoceR ,(1991),repaP dehsilbupnU, neM esenapaJ fo seliforP .ytisrevinU etatS aniloraC htroN

[37] orihoaN , awagO dna.L treboR, kralC tnemeriteR yrotadnaM fo tceffE ehT,(a1992) dna lairtsudnI,napaJ ni seliforP sgninraE no .258-66:(2)45, weiveR snoitaleR ruobaL

[38] orihoaN ,awagO dna.L treboR , kralC sgninraE dna eruneT tnemyolpmE ,(b (1992)

[39]F.J.Schwarz, S.J.Pharr et al, The State of Civil Society in Japan, Cambridge University 


\section{Press2003 .}

[40]See J.A.A.Stockwine; Dicitionary of the Modern Politics of Japan, Routledge Curzon, ,2003 p.53.

How to cite this article:

Molaee E and Emadzadeh K. Study official non- concentration system benefits by emphasize to Sapan. J. Fundam. Appl. Sci., 2016, 8(3S), 420-429. 